\title{
Date of Performance Status Assessment
}

National Cancer Institute

\section{Source}

National Cancer Institute. Date of Performance Status Assessment. NCI Thesaurus.

Code C156913.

The date of the Performance Status Assessment. 